\title{
Forecasting Future Beach Width-A Case Study Along the Florida Atlantic Coast
}

By Joseph W. Long, Rachel E. Henderson, and David M. Thompson

Open-File Report 2019-1150

U.S. Department of the Interior

U.S. Geological Survey 


\title{
U.S. Department of the Interior \\ DAVID BERNHARDT, Secretary
}

\author{
U.S. Geological Survey \\ James F. Reilly, Director
}

U.S. Geological Survey, Reston, Virginia: 2020

For more information on the USGS-the Federal source for science about the Earth, its natural and living resources, natural hazards, and the environment-visit https://www.usgs.gov/ or call 1-888-ASK-USGS (1-888-275-8747).

For an overview of USGS information products, including maps, imagery, and publications, visit https://store.usgs.gov/.

Any use of trade, firm, or product names is for descriptive purposes only and does not imply endorsement by the U.S. Government.

Although this information product, for the most part, is in the public domain, it also may contain copyrighted materials as noted in the text. Permission to reproduce copyrighted items must be secured from the copyright owner.

Suggested citation:

Long, J.W., Henderson, R.E., and Thompson, D.M., 2020, Forecasting future beach width—A case study along the Florida Atlantic coast: U.S. Geological Survey Open-File Report 2019-1150, 13 p., https://doi.org/10.3133/ofr20191150.

ISSN 2331-1258 (online) 


\section{Acknowledgments}

The U.S. Fish and Wildlife Service chartered this research, and Kara Doran of the U.S. Geological Survey St. Petersburg Coastal and Marine Science Center was instrumental in data discovery. 


\section{Contents}

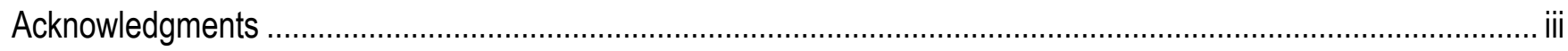

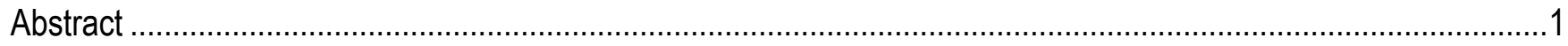

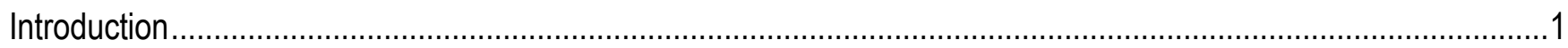

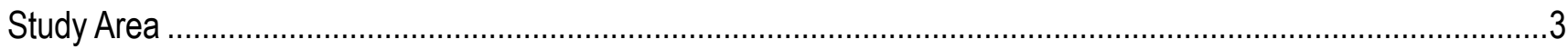

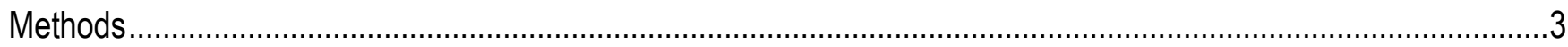

Historical Shoreline and Dune-Base Positions .........................................................................................

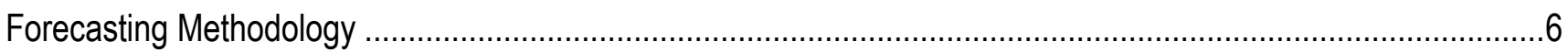

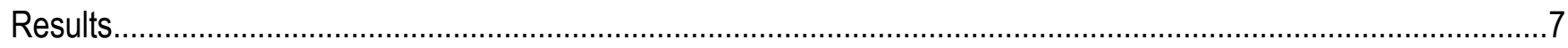

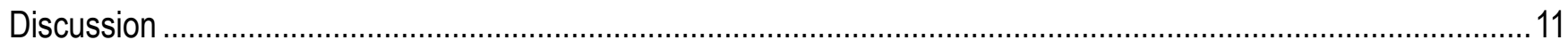

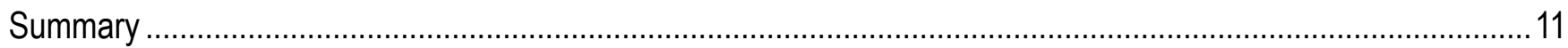

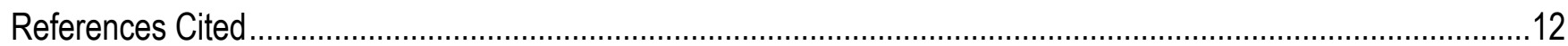

\section{Figures}

1. Image maps and schematic showing: $A$, example shoreline-perpendicular transects and baseline for Cape Canaveral, Florida; $B$, yellow transect that identifies the cross-shore transect with the shoreline and dune base positions; and $C$, schematic that denotes the coastal features identified from datasets and the definition of beach width

2. Scatter plots showing intersects on a shore-perpendicular transect for: $A$, shoreline and $B$, dune base at Cape Canaveral, Florida

3. Map and graphs illustrating: $A$, the extent of the shoreline and dune-base forecast locations; $B$, the year of the first available shoreline and dune-base positions for each transect; $C$, most recent shoreline and dune-base positions for each transect; and $D$, total number of shoreline and dune-base positions used in the analysis.

4. Graph and map image showing: $A$, forecast of the shoreline and dune-base position at the transect shown in $B$, a coastal section of Hutchinson Island, Florida.

5. Graph and map image showing: $A$, forecast of the shoreline and dune-base position at the transect shown in $B$, a coastal section of Cape Canaveral, Florida

6. Graph and map showing: $A$, forecast of the shoreline and dune-base position; and $B$, section of Vilano Beach, Florida, with the forecasted 2028 shoreline and dune-base positions and uncertainty......

7. Map and graphs illustrating: $A$, extent of the shoreline and dune-base forecast locations; $B$, beach width computed from the 2017 lidar-derived dune-base and shoreline observations and the forecasted 2028 beach width; and C, change in beach width from 2017 to 2028 at every shore-perpendicular transect and smoothed with 5-kilometer alongshore Hanning-shaped window

8. Histograms of the change in: $A$, beach width in meters; and $B$, percent change in beach width for all shoreperpendicular transects 


\section{Conversion Factors}

International System of Units to U.S. customary units

\begin{tabular}{lcll}
\hline & Multiply & By & To obtain \\
\hline & Length & & \\
\hline centimeter $(\mathrm{cm})$ & 0.3937 & inch (in.) & \\
meter $(\mathrm{m})$ & 3.281 & foot (ft) & \\
kilometer $(\mathrm{km})$ & 0.6214 & mile (mi) & \\
\hline
\end{tabular}

\section{Datum}

Vertical coordinate information is referenced to the North American Vertical Datum of 1988 (NAVD 88).

Horizontal coordinate information is referenced to the North American Datum of 1983 (NAD 83).

Elevation, as used in this report, refers to distance above the vertical datum.

\section{Abbreviations}

DPS distinct population segment

HWL high-water lines

km kilometer

m meter

MHW mean high water 


\title{
Forecasting Future Beach Width-A Case Study Along the Florida Atlantic Coast
}

\author{
By Joseph W. Long, ${ }^{1}$ Rachel E. Henderson, ${ }^{2}$ and David M. Thompson ${ }^{2}$
}

\begin{abstract}
Historical cross-shore positions of the shoreline and dune base were used as inputs for a Kalman filter algorithm to forecast the positions of these features in the year 2028. The beach width was also computed as the cross-shore distance between the forecasted 2028 shoreline and dune-base positions. While it does not evaluate the suitability of a nesting beach or identify optimal nesting habitat, the beach width can be used as a proxy for habitat availability. An analysis was conducted along the Florida Atlantic coast with an initial goal of demonstrating a method that combines available data for shoreline and dune positions with a Kalman Filter algorithm developed to predict decadal-scale shoreline evolution and then uses these features to define future beach width. This section of the southeastern United States hosts the largest assemblage of nesting loggerhead sea turtles (Caretta caretta) in the world, in addition to other species, and critical habitat is designated as part of the species' listing package under the Endangered Species Act of 1973 (16 U.S.C. ch. $35 \S 1531$ et seq) for most of the nesting beaches within the study area. This work introduces an approach to inform ecosystem services assessments using data typically derived for shoreline change and storm vulnerability models.
\end{abstract}

\section{Introduction}

The shoreline represents an important ephemeral boundary that separates terrestrial and marine environments. Changes in shoreline positions across time are used to describe the trajectory of the coastal environment and as a metric to quantify the vulnerability of coastal infrastructure and ecosystem services. Other coastal features used to characterize the state of sandy beach environments include the position and elevation of the dune base and crest and the width of the subaerial beach (fig. 1). Although not often used in coastal assessments, beach width can influence the quantity of sandy beach habitat used by species, as with the nesting of marine turtles. Beach width alone does not define optimal or suitable nesting-beach habitat for a species; however, assessing changes in beach width is important for understanding how the area available for nesting habitat has changed and is likely to evolve.

Shorelines, sand dunes, and beach width evolve over different time scales that range from days to decades because the movement is dictated by a combination of oceanographic (short and long-term changes in waves and water levels), geomorphic (for example, increases or decreases in sediment supply), and anthropogenic (for example, beach nourishment and infrastructure) influences. For instance, the position of the shoreline changes hourly with each tidal cycle, seasonally with changes in the offshore waves (Yates and others, 2009; Ludka and others, 2015), and infrequently, but abruptly, due to the effects of large tropical storms (Robertson and others, 2007) and beach nourishment projects. On the other hand, waves and water levels only reach and erode the location of the dune base landward during large but low-frequency storm events (for example, Splinter and others, 2018). During other times, the

\footnotetext{
${ }^{1}$ University of North Carolina Wilmington.

${ }^{2}$ U.S. Geological Survey St. Petersburg Coastal and Marine Science Center.
} 
base of the dune can prograde due to wind-blown sediment transport (Houser and others, 2015) or can be affected by occasional beach nourishment projects.

Tools are needed to forecast the trajectory of these coastal features over the next decade so that informed management decisions can be made. Previous efforts focused on assessing changes to the shoreline position rather than other features of the coastal system, such as dune base and beach width
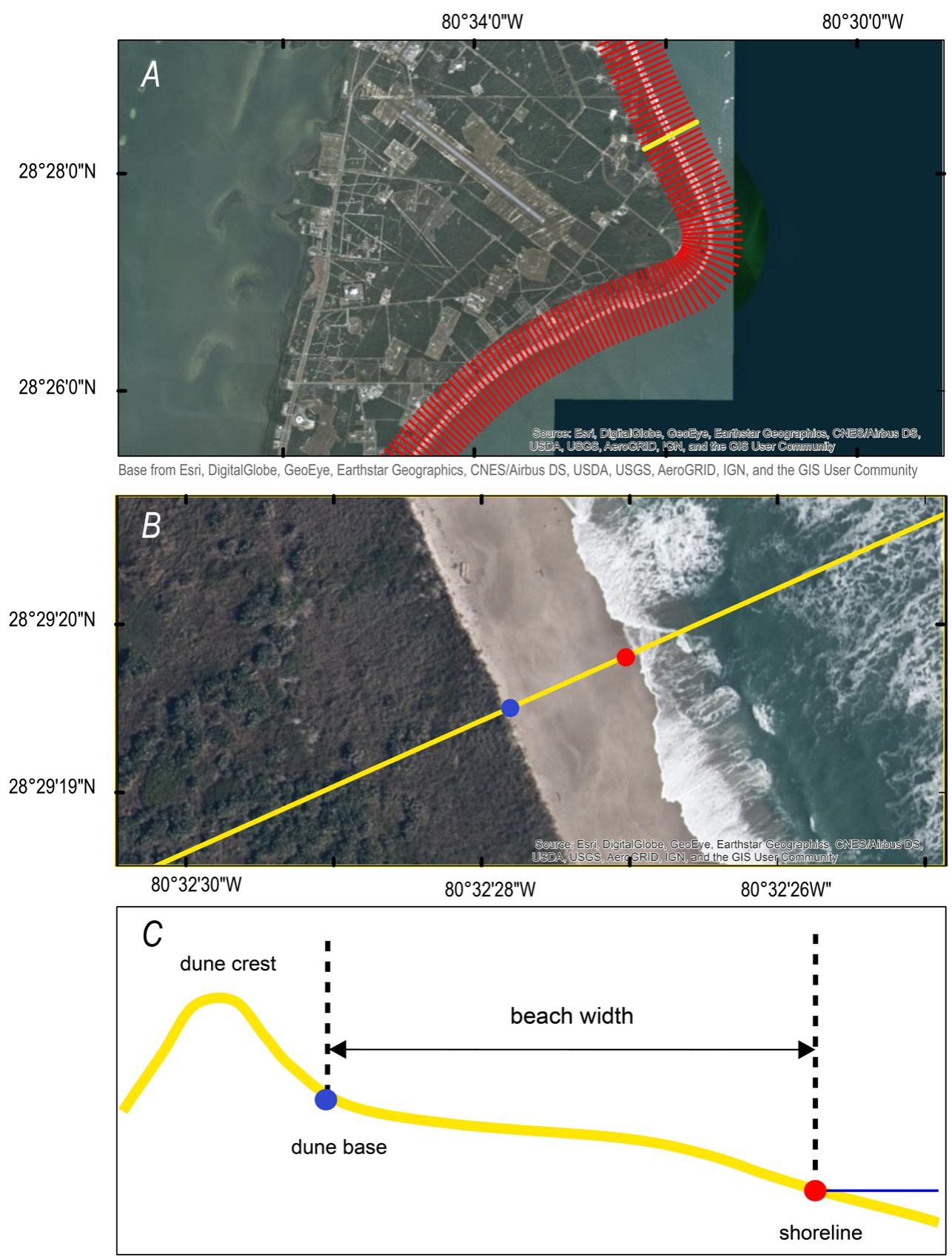

Figure 1. Image maps and schematic showing $(A)$ example shoreline-perpendicular transects (red) and baseline (white) for Cape Canaveral, Florida, used to analyze cross-shore changes in shoreline and dune positions. $(B)$ Yellow transect that identifies the cross-shore transect with the shoreline and dune base positions (red and blue dots, respectively). (C) Schematic denotes the coastal features identified from datasets and the definition of beach width. 
(for example, Yates and others, 2009; Davidson and others, 2010; Hapke and others, 2011). Decadal projections inherently integrate across shorter-term erosion and recovery cycles and can help guide management or restoration decisions aimed at longer-term sustainability. Understanding the decadal trajectory is essential to making proactive, rather than reactive, decisions that balance the competing needs of protecting nesting habitat and protecting coastal infrastructure. This knowledge also aids in prioritizing resources to address those areas most at risk. Assessments of how the dune base and beach width evolve are required for making these decisions, specifically for species that nest on the beach, but assessments of this type do not currently exist. Furthermore, although numerous studies computed shoreline change across history and in many locations, few used these observations to forecast changes formally.

The primary objective of this work is to use data originally derived for storm-vulnerability assessments and use them to extend algorithms developed to predict beach characteristics along the Florida Atlantic coast for the year 2028. Forecasted characteristics include the following:

- Shoreline position and uncertainty,

- Dune-base position and uncertainty,

- Beach width, and

- A comparison of the forecasted 2028 beach width with modern conditions.

Changes in the elevation of dune features, which are important indicators of optimal habitat suitability, were not considered in this study but are a logical extension of this work. The same methodology used in this report could be used for further research.

\section{Study Area}

The study area includes the Atlantic Coast of Florida from the Florida-Georgia border in the north to Miami in the south. This section of coast was chosen, in part, because it is crucial to the longterm sustainability of the loggerhead sea turtle (Caretta caretta) Northwest Atlantic Ocean distinct population segment (DPS). Many sections of this coast were designated as critical habitat under the Endangered Species Act of 1973. This stretch of coastline is heavily developed, and the shoreline is regularly altered by sand placement, inlet management, and jetties-groin systems, and it is routinely affected by extreme storms.

A set of transects, 5,796 in total, spaced 10-meters (m) apart alongshore, were cast perpendicular to a reference baseline that follows the modern Florida Atlantic shoreline (fig. $1 \mathrm{~A}$ ). The distance between the baseline and the intersection of each historical shoreline and dune-base position were determined for each transect (fig. 2). Transects without at least two shoreline and dune-base intersects were excluded from analysis, leaving 4,581 useable transects where forecasts could be made.

\section{Methods}

Forecasts of the 2028 shoreline and dune-base positions were made using a Kalman filter algorithm (Long and Plant, 2012) combined with historical, previously published feature positions derived from airborne lidar surveys (shorelines and dune base), and orthorectified aerial imagery (for shorelines only). While additional aerial photographs, lidar surveys, or ground-based elevation surveys may be available on small sections of the coast from local municipalities or State sources, no new features were derived as part of this project. Instead, the goal was to develop a consistent methodology using a previously published time series of these features to build a regional forecasting framework for quantifying future beach width. The year 2028 was chosen because it was the 10 -year time horizon at the start of the project. 
The Kalman filter can take past observations of the shoreline and dune positions to forecast future positions and determine a level of uncertainty in the forecast (Long and Plant, 2012; Vitousek and others, 2017). The observations used in the Kalman filter represent temporal snapshots of each feature's position, and the forecasted-feature evolution is driven by the combination of all the oceanographic, geomorphic, and anthropogenic processes that affect feature positions at each coastal location. This approach does not determine the relative contribution of each force driving coastal evolution but assumes that the same forces persist into the future. Therefore, the forecast represents a "business as usual" scenario relative to historical storm frequency, beach nourishment cycles, a fixed coastal infrastructure, and similar limits to variability.

\section{Historical Shoreline and Dune-Base Positions}

The historical, cross-shore positions of the shoreline and seaward-most dune base are available from Himmelstoss and others (2017) (photograph-based and map-based shoreline positions) and Doran and others (2018) (lidar-based shoreline and dune positions). Shoreline data include the combination of high-water lines (HWL) digitized from orthorectified aerial photography or historical survey maps (t-sheets) and the location of the mean high water (MHW) elevation extracted from airborne lidar surveys (techniques described in Stockdon and others, 2002; Weber and others, 2005). These data represent snapshots in time of shoreline and dune positions, and the availability of these data vary by location. In
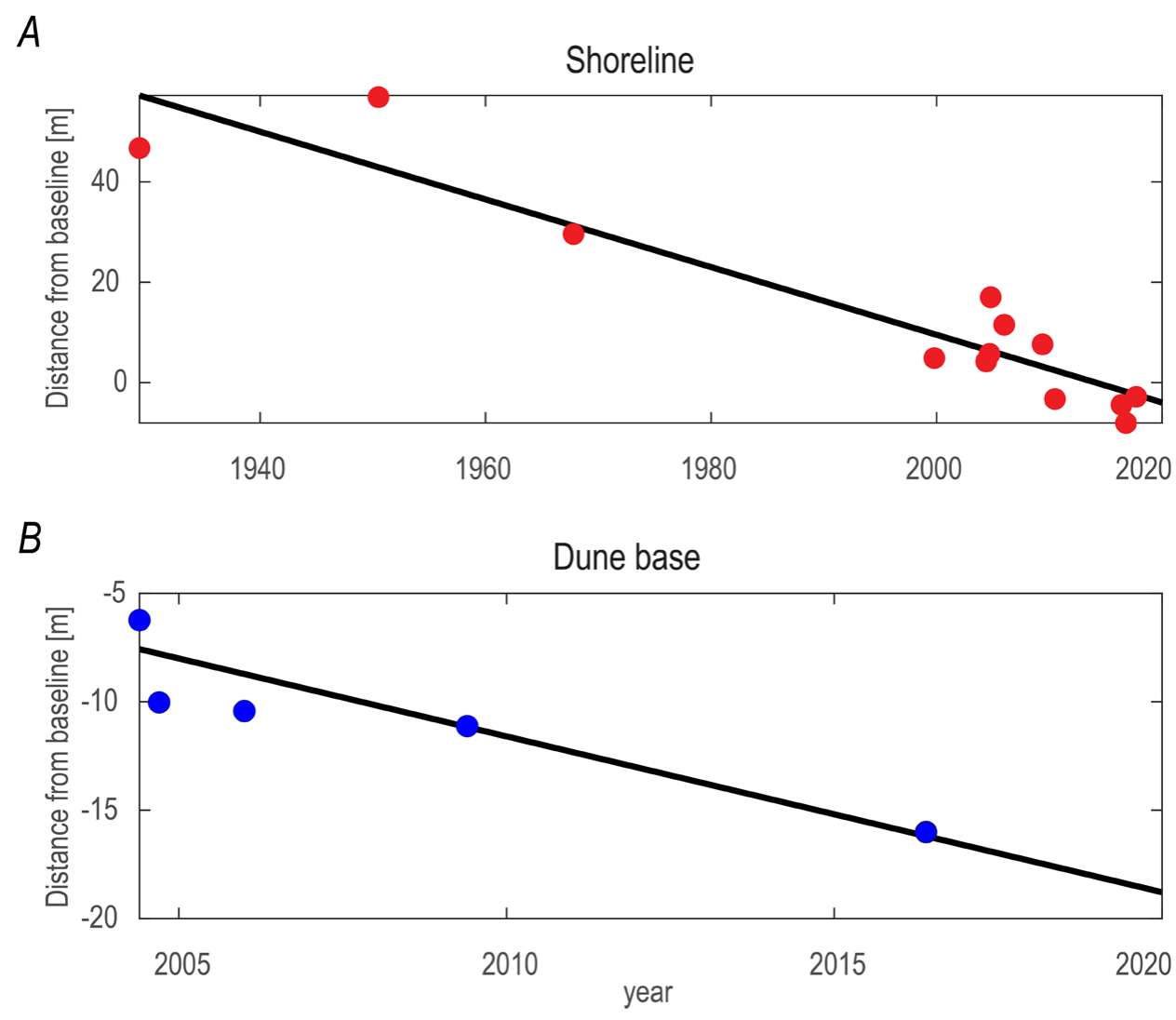

Figure 2. Scatter plots showing intersects on a shore-perpendicular transect for the $(A)$ shoreline and $(B)$ dune base at Cape Canaveral, Florida, in meters $(m)$. Intersects (red and blue circles for shoreline and dune-base positions, respectively) are relative to the reference baseline shown in figure 1. Black line shows a standard least-squares regression. The same procedure is repeated at each of the 4,581 transect locations. Note the different limits along the $x$-axis due to differences in data availability. 
general, map-based shorelines date back to the late 1800s, photograph-based shorelines date from the mid-1900s to the present, and lidar-derived shorelines are available after 1999. While features extracted from lidar data are referenced to a tidal datum, shorelines from the aerial imagery and t-sheets are not corrected for tide elevation. Figure 3 shows the date of the first, most recent, and total number of shoreline positions in the study area. On average, along this stretch of coastline, there were 11-12 shoreline observations found at each transect and used in the analysis. The error and uncertainty in each of these observations results from image georeferencing, manual shoreline digitization, lidar instrument noise, and more. In general, errors in the photograph-based shoreline are higher than those derived from lidar shorelines. A complete summary of the type and magnitude of these errors is found in Morton and others (2004) and Stockdon and others (2002). Note that the HWL and MHW are not identical measurements of the shoreline, but no bias correction of the HWL was performed (for example, Ruggiero and List, 2009). Potential uncertainty introduced by merging these metrics (up to approximately $10 \mathrm{~m}$ in the horizontal for individual shoreline observations) is included in the Kalman filter. Therefore, further use of the term shoreline is technically neither the HWL or MHW but instead a general measure of the land-water interface.

The location of the dune base is not easily discernible from aerial photographs; therefore, the dune base is only available from lidar elevation surveys (1999 to present). The position of the dune base is traditionally defined as the location between the shoreline and dune crest, where the curvature of the beach profile is greatest. A complete description of the methods used for lidar-based feature extraction is available in Stockdon and others (2012). The study area covered by this report had an average of 4-5 dune-base positions available at each transect for use in making forecasts.

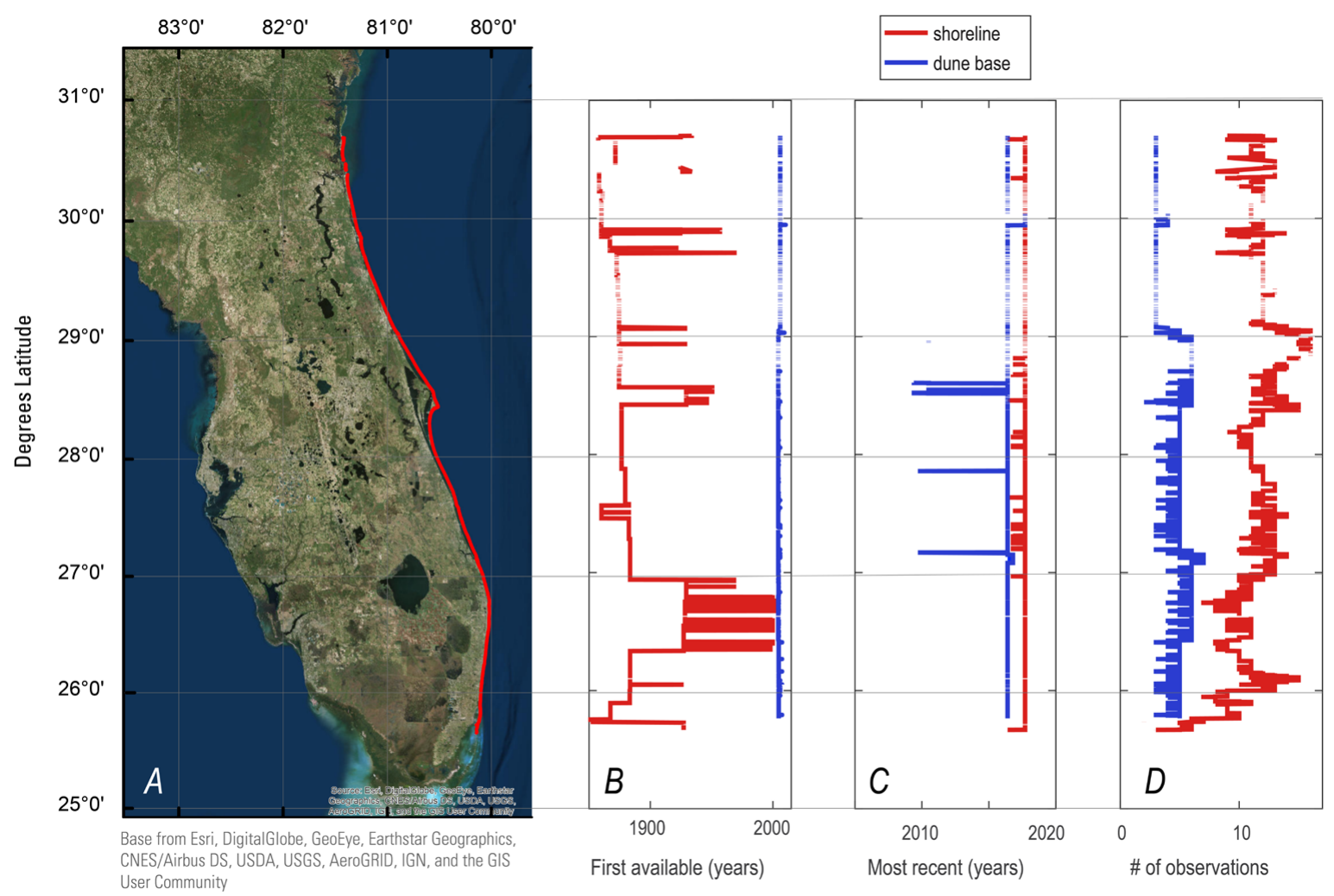

Figure 3. Map and graphs illustrating $(A)$ the extent of the shoreline and dune-base forecast locations (red). The year of $(B)$ the first available and $(C)$ most recent shoreline (red) and dune-base (blue) positions are provided for each transect.

(D) Total number of shoreline and dune-base positions used in the analysis are also shown. \#, number. 


\section{Forecasting Methodology}

The shoreline and dune-base position forecast is performed independently at each shore-perpendicular transect. The Kalman filter method provides a way to combine observations of shoreline or dune-base change with a model of how they are expected to change (for example, Kalman, 1960; Haykin, 2001). Because the focus is on decadal-scale changes rather than day-to-day or seasonal observations of the beach, the input to the Kalman filter is a linear equation:

Where

$$
x(t+d t)=x(t)+v * d t
$$

$x \quad$ is the feature position relative to the reference baseline;

$t \quad$ is time, in months;

$d t \quad$ is the time step; and

$v \quad$ is the rate of change of the feature position in time.

The time-stepping algorithm starts with the date of the first observation (for example, fig. $3 B$ ) and continues through the year 2028 with a constant time step of 0.1 years. At time steps where no observations are available, the Kalman filter propagates the model prediction forward in time using the above equation. At any time step where an observation is available, the Kalman filter corrects the predicted feature position by using the observation. The algorithm adjusts the feature positions and updates the rate of change. While the Kalman filter is initialized with a rate of change determined by a least-squares regression of the historical feature positions, it can detect periods when that rate might shift (for example, an acceleration or deceleration in how quickly the feature position is changing). These shifts can be the result of many processes, including sea-level rise, more intense storms, and coastal development.

A measure of the uncertainty in the feature position is also determined at each time step. When observations are available to correct the prediction, the uncertainty is reduced. At time steps without an available observation, the uncertainty increases until another observation is available. Therefore, from the time of the last observation to the 2028 forecast horizon, the uncertainty in the prediction steadily increases. A more complete description of the Kalman filter and its application to shoreline-change models is available in Long and Plant (2012).

Aside from the observations of feature positions, the other parameters required by the Kalman filter are estimates of process and measurement noise. These estimates are required so that when the Kalman filter merges information from the model and the data, it can statistically combine them by considering the amount of potential error in both the model and observation. Process noise refers to errors in the model used to predict the position of each coastal feature. In this study, it is assumed that the decadal trend is linear, although, by including process noise, it is acknowledged that the model is imperfect and that the rate of change of the shoreline and dune-base positions may not be constant. The greater the process-noise value, the lower the certainty about the chosen model. A value of 0.1 is used for the shoreline forecast and a value of 0.0001 is used for the dune position forecast, consistent with the methods of Long and Plant (2012). A higher value of process noise is given to the shoreline forecast because a wider range of processes affect shoreline position. Measurement noise refers to errors in the observed feature positions. These values are different for each observation. For instance, lidar-based shorelines have a lower error value than shorelines digitized from aerial photographs. These errors are all documented in the original data sources referenced above. 


\section{Results}

The primary results of this study are the forecasted shoreline and dune-base positions along the Florida Atlantic coast, which can be used to make scientifically defensible management decisions. A set of example outputs from three regions is provided below.

An example of the forecasted shoreline and dune position for a section along Hutchinson Island, Fla., is shown in figure 4. Red and blue colors denote the positions (solid line) and uncertainty (shaded region) in the shoreline and dune-base positions, respectively. Alongshore variability in the predictions is apparent, especially in the position of the dune base. A short seawall constructed in this area keeps

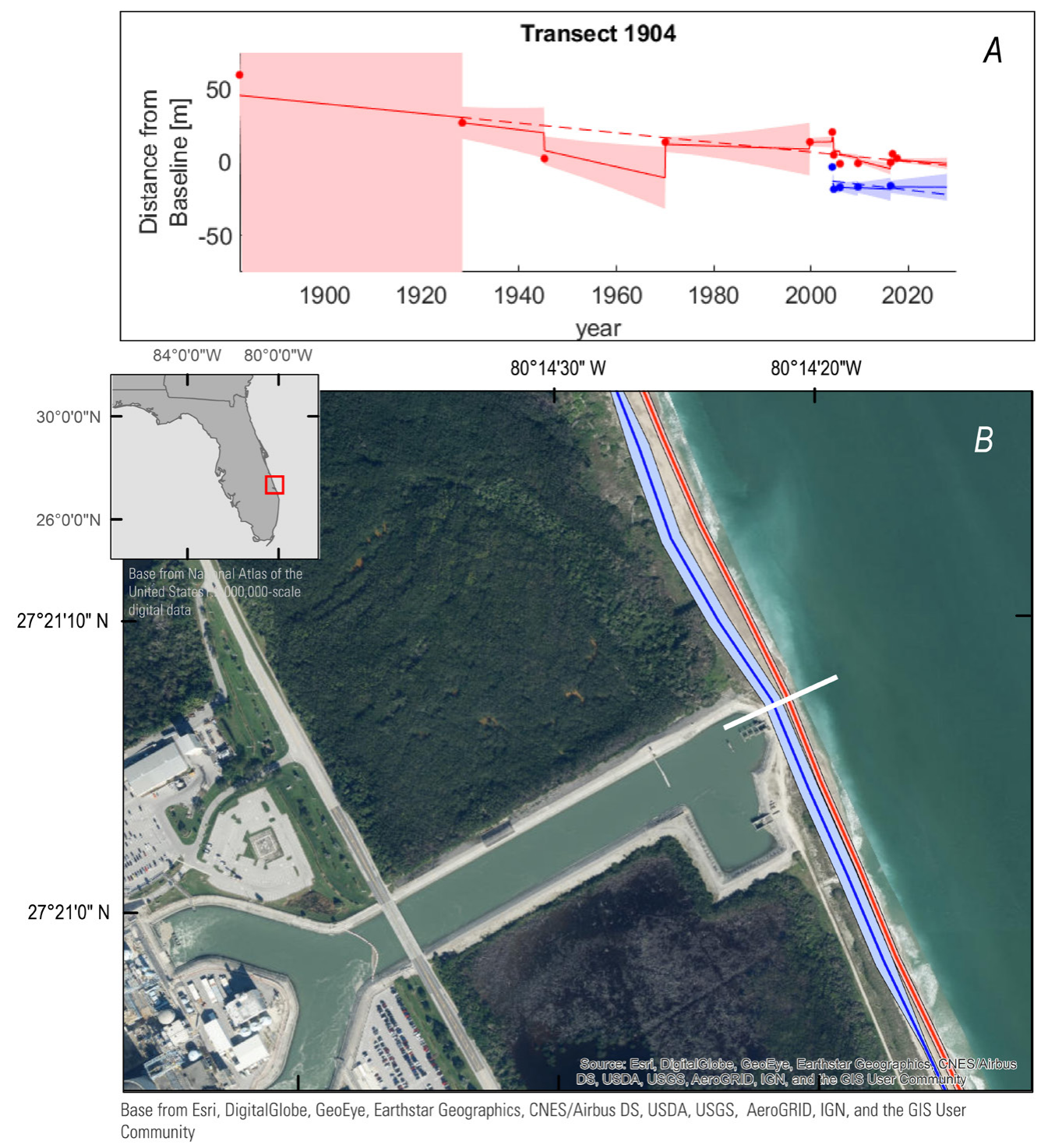

Figure 4. Graph and map image showing $(A)$ a forecast of the shoreline and dune-base position (in meters $[\mathrm{m}]$ ) at the transect (white line) in (B) a coastal section of Hutchinson Island, Florida. Red and blue lines in $A$ denote the shoreline and dune base, respectively. Solid lines represent the Kalman filter prediction, dashed lines are the standard least-squares regression, and dots represent observations. Red and blue shaded areas are the forecast uncertainty. $B$ shows the forecasted 2028 shoreline (red line), dune-base (blue line) positions, and uncertainty (shaded red and blue). 
the predicted dune-base position from migrating landward as far as adjacent sections of the coastline. Similar alongshore variations in the predicted dune-base position are illustrated in figure 5 for a section of coastline along Cape Canaveral, Florida. Despite the landward migration of both the shoreline and dune base at this location, the beach width remains relatively constant (note that the distance between the shoreline and dune-base positions remains constant through time). A final example from the Vilano Beach, Fla., area is shown in figure 6. This area is a developed section of coastline with infrastructure present near the dune line. At this location, the beach width is forecast to decrease in 2028 as the shoreline migrates landward, and the dune-base position remains relatively stable.

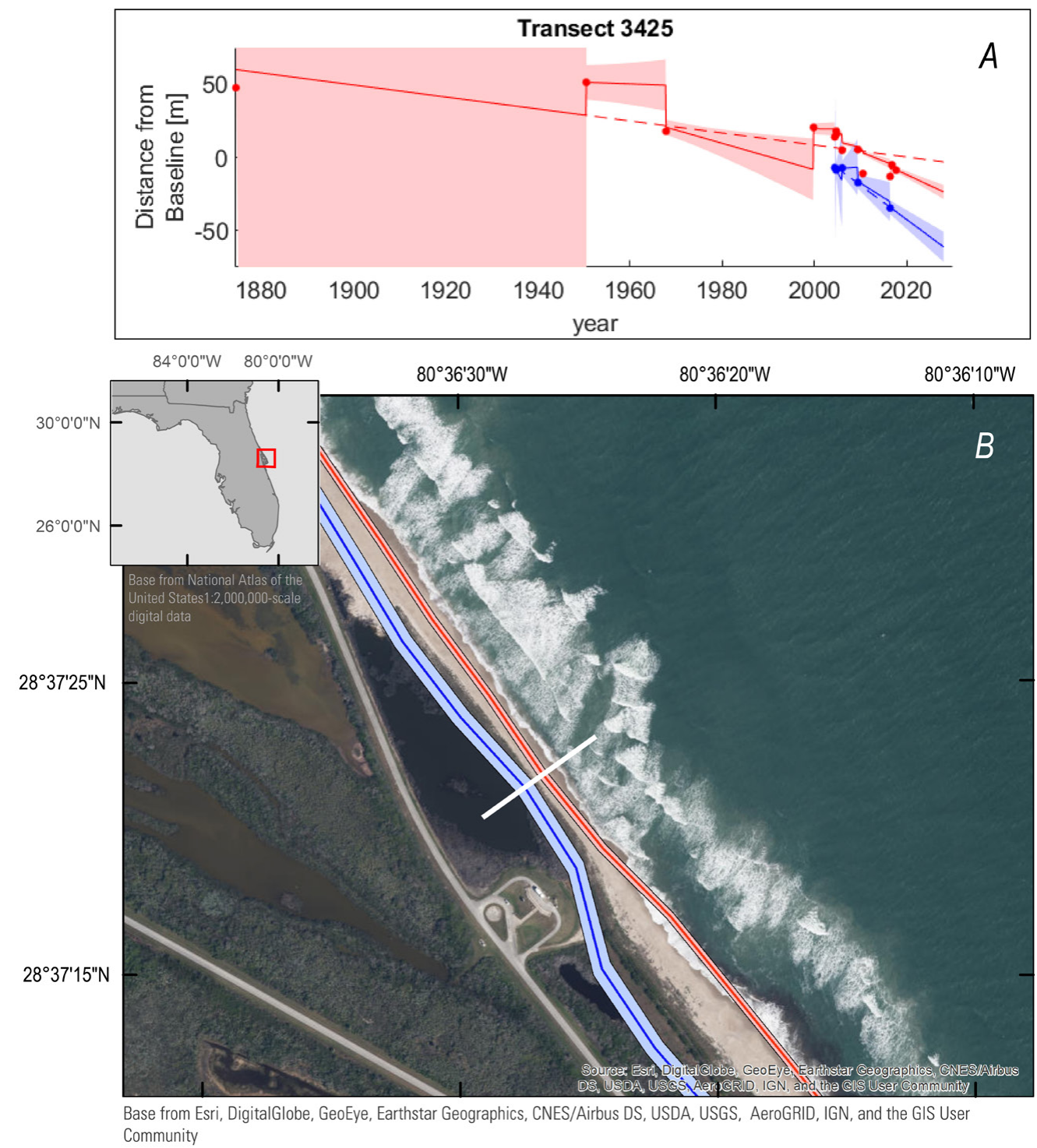

Figure 5. Graph and map image showing $(A)$ forecast of the shoreline and dune-base position (in meters [m]) at the transect (white line) in $(B)$ a coastal section of Cape Canaveral, Florida. Red and blue lines in $A$ denote the shoreline and dune base, respectively; solid lines represent the Kalman filter prediction, dashed lines are the standard least-squares regression, and dots represent observations. Red and blue shaded areas are the forecast uncertainty. B shows the forecasted 2028 shoreline (red line), dune-base (blue line) positions, and uncertainty (shaded red and blue). 
An analysis of the change in beach width between current conditions and the 2028 forecast indicates conditions are highly variable along the entire study area (fig. 7). Of the 4,581 transects, 42 percent exhibit a decrease in beach width and, therefore, available species nesting habitat. Along beaches north and south of Cocoa Beach, Fla., 35 percent and 45 percent are expected to become narrower, respectively. A histogram of the percent change in beach width for all transects is provided in figure 8 and indicates a symmetrical distribution with a mean of -3.25 percent along the study area. However, some locations exist where the dune base is expected to erode landward faster than the shoreline (for example, fig. 8). While this increases beach width, it may not be a desirable outcome if resources along the coast are threatened by a recession of the dune base. Also, this change is not an assurance that the wider beach would provide suitable habitat for marine turtle nesting.

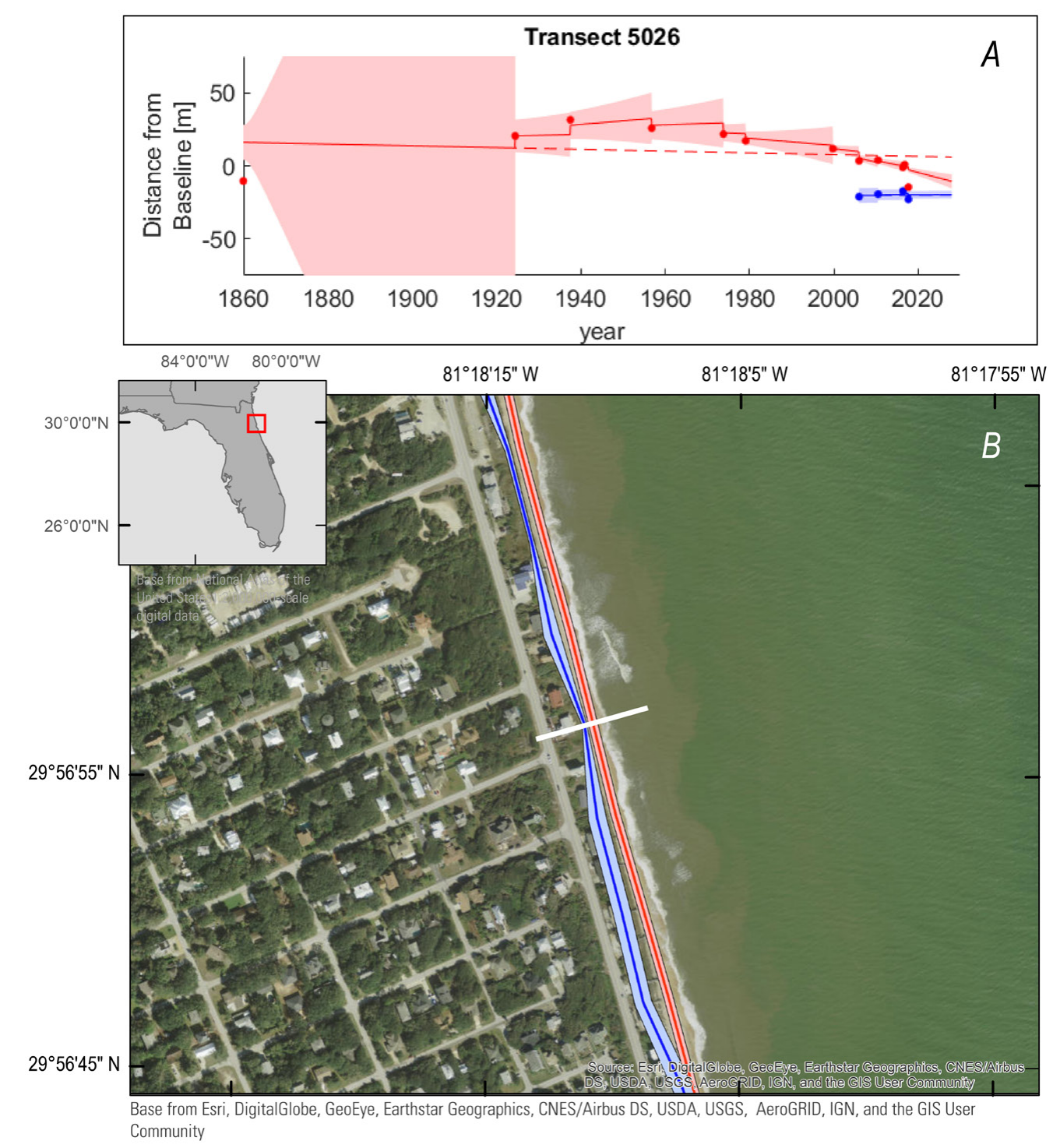

Figure 6. Graph and map showing $(A)$ forecast of the shoreline and dune-base position (in meters [m]) at the transect (white line). Red and blue denote the shoreline and dune base, respectively. Solid lines represent the Kalman filter prediction, dashed lines are the standard least squares regression, and dots represent observations. Red and blue shaded areas are the forecast uncertainty. $(B)$ Section of Vilano Beach, Florida, with the forecasted 2028 shoreline (red line) and dune-base (blue line) positions and uncertainty (red and blue shading). 


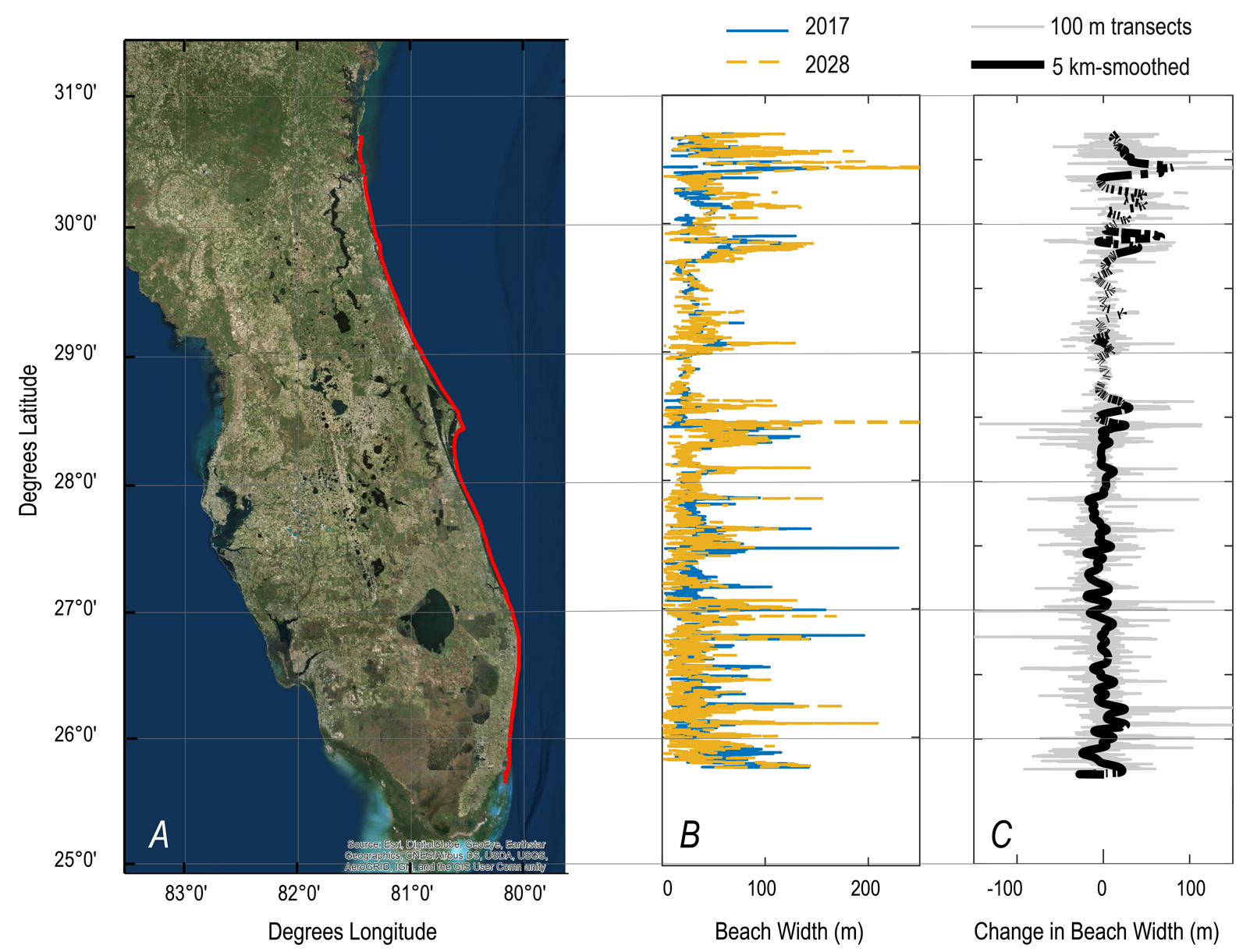

Figure 7. Map and graphs $(A)$ illustrating the extent of the shoreline and dune-base forecast locations (red). (B) Beach width computed, in meters $(\mathrm{m})$, from the 2017 lidar-derived dune-base and shoreline observations (blue solid) and the forecasted 2028 beach width (yellow dashed). (C) Change in beach width, in m, from 2017 to 2028 at every shore-perpendicular transect (grey) and smoothed with 5-kilometer (km) alongshore Hanning-shaped window (black). Negative indicates a loss in beach width in 2028 compared with 2017.
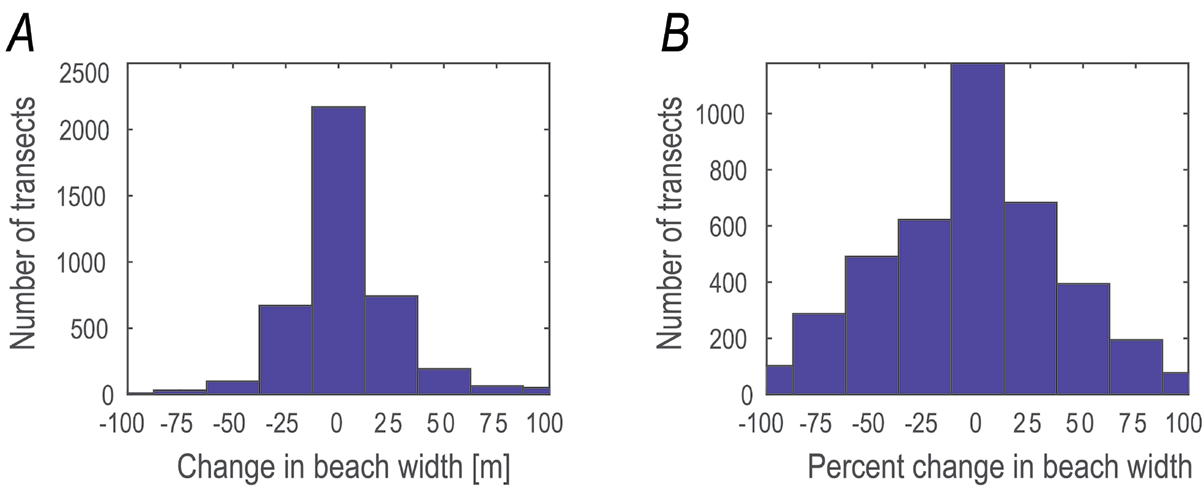

Figure 8. Histograms of the change in $(A)$ beach width, in meters $(m)$, and $(B)$ percent change in beach width for all shore-perpendicular transects. Bin width $=10 \mathrm{~m}$. 


\section{Discussion}

The forecasted 2028 shoreline and dune positions represent decadal-scale trends in the movement of these coastal features. The forecasted positions are not intended to provide the exact location of either feature on any given day or time; instead, they offer guidance about the longer term trajectory of these critical coastal metrics. The observations used to drive the forecast inherently include the complex interactions between large storms, coastal construction, changes in longshore sediment transport, and other processes. Disentangling these processes was not the intent of this research; developing an understanding of the decadal-scale trajectory that results from the combination of these factors can help eliminate management decisions based on a single event (for example, construction of seawalls following a major storm event before beaches have a chance to recover naturally).

More data across time lead to more robust forecasts. However, for this work, a low threshold on the number of data points (two per feature) was used due to a lack of data in some sections. The lack of data is reflected in the forecast uncertainty at each transect, as uncertainty in the algorithm continues to grow until observations are available to correct the prediction. It is also possible that at some locations the majority of the lidar surveys used to derive the positions of the features were conducted immediately before or after a storm event. Pre- and post-storm surveys are often used to assess the coastal change driven by these storms, but using these data could bias change rates toward how a beach responds to a single process. Finally, while rare, the dune-base position identified in the lidar elevation data could be associated with a secondary dune field in post-storm elevation data if the storm event completely eroded the most seaward dune.

Specific future scenarios of sea-level rise were not included in the analysis. The forecast using the Kalman filter approach uses past observations to forecast future conditions. The evolution of a beach is constantly driven by combinations of sea-level rise, storm effects, and nourishments; this kind of assessment assumes that the same combination and rate of physical drivers continues. Therefore, if sea-level change causes certain areas to erode at a defined rate, that rate can be identified by the Kalman filter and used in the forecasted positions.

The Kalman filter algorithm applied here was used in other studies (Long and Plant, 2012; Vitousek and others, 2017), but there are some parameters used in the algorithm, particularly the level of process noise, that are not well documented and are difficult to constrain. Constant values were chosen for this application, but further research and sensitivity analyses are needed.

\section{Summary}

Historical observations of shoreline and dune-base positions were combined with a Kalman filter algorithm to forecast coastal shoreline and dune positions and uncertainty for the year 2028. Beach width, defined as the distance from the shoreline to the dune base, was computed for each location to provide a forecast of available beach. The methods used in this report are intended for regional scales and represent an extension to previous efforts that focused only on shoreline positions or historical rates of change without offering future projections. The beach-width metric does not address the suitability of habitat, which incorporates other aspects of the beach environment, including dune elevations, beach and dune slope, sediment characteristics, presence of beach scarps, and many other elements.

While designed to assess potential nesting-beach areas, these results can be applied to a wide range of applications, including storm vulnerability assessment, coastal construction regulations, and more. The results can also be used to link assessments across disciplines and agencies (for example, the U.S. Geological Survey and the U.S. Fish and Wildlife Service), identify data gaps that require research efforts, and prioritize resources to those areas most at risk. 


\section{References Cited}

Davidson, M.A., Lewis, R.P., and Turner, I.L., 2010, Forecasting seasonal to multi-year shoreline change: Coastal Engineering, v. 57, no. 6, p. 620-629, accessed June 15, 2010, at https:// doi.org/10.1016/j.coastaleng.2010.02.001.

Doran, K.S., Long, J.W., Birchler, J.J., Brenner, O.T., Hardy, M.W., Morgan, K.L.M, Stockdon, H.F., and Torres, M.L., 2019, Lidar-derived beach morphology (dune crest, dune toe, and shoreline) for U.S. sandy coastlines (ver. 2.0, August 2018): U.S. Geological Survey data release, accessed May 15, 2019, at https://doi.org/10.5066/F7GF0S0Z.

Hapke, C.J., Himmelstoss, E.A., Kratzmann, M.G., List, J.H., and Thieler, E.R., 2011, National assessment of shoreline change-Historical shoreline change along the New England and Mid-Atlantic coasts (rev. April 2012): U.S. Geological Survey Open-File Report 2010-1118, 57 p., accessed May 15, 2019, at https://pubs.usgs.gov/of/2010/1118/.

Haykin, S. (ed.), 2001, Kalman filtering and neural networks: New York, John Wiley, 284 p.

Himmelstoss, E.A., Kratzmann, M.G., and Thieler, E.R., 2017, National assessment of shoreline changeSummary statistics for updated vector shorelines and associated shoreline change data for the Gulf of Mexico and Southeast Atlantic coasts: U.S. Geological Survey Open-File Report 2017-1015, 8 p., accessed November 26, 2019, at https://doi.org/10.3133/ofr20171015.

Houser, C., Wernette, P., Rentschlar, E., Jones, H., Hammond, B., and Trimble, S., 2015, Post-storm beach and dune recovery-Implications for barrier island resilience: Geomorphology, v. 234, April, p. 54-63, accessed October 29, 2015, at https://doi.org/10.1016/j.geomorph.2014.12.044.

Kalman, R.E., 1960, A new approach to linear filtering and prediction problems: Journal of Basic Engineering, v. 82, no. 1, p. 35-45, accessed February 10, 2012, at https://doi.org/10.1115/1.3662552.

Long, J.W., and Plant, N.G., 2012, Extended Kalman filter framework for forecasting shoreline evolution: Geophysical Research Letters, v. 39, no. 13, L13603, 6 p., accessed July 7, 2012, at https:// doi.org/10.1029/2012GL052180.

Ludka, B.C., Guza, R.T., O’Reilly, W.C., and Yates, M.L., 2015, Field evidence of beach profile evolution toward equilibrium: Journal of Geophysical Research-Oceans, v. 120, no. 11, p. 7574-7597, accessed May 15, 2019, at https://doi.org/10.1002/2015JC010893.

Morton, R.A., Miller, T.L., and Moore, L.J., 2004, National assessment of shoreline change-Part 1, Historical shoreline changes and associated coastal land loss along the U.S. Gulf of Mexico: U.S. Geological Survey Open-File Report 2004-1043, 42 p., accessed May 15, 2018, at https://doi.org/10.3133/ ofr20041043.

Robertson, W., Zhang, K., and Whitman, D., 2007, Hurricane-induced beach change derived from airborne laser measurements near Panama City, Florida: Marine Geology, v. 237, nos. 3-4, p. 191-205, accessed May 15, 2018, at https://doi.org/10.1016/j.margeo.2006.11.003.

Ruggiero, P., and List, J.H., 2009, Improving accuracy and statistical reliability of shoreline position and change rate estimates: Journal of Coastal Research, v. 25, no. 5, p. 1069-1081. [Also available at https:// doi.org/10.2112/08-1051.1.]

Splinter, K.D., Kearney, E.T., and Turner, I.L., 2018, Drivers of alongshore variable dune erosion during a storm event-Observations and modelling: Coastal Engineering, v. 131, January, p. 31-41, accessed May 15, 2018, at https://doi.org/10.1016/j.coastaleng.2017.10.011. 
Stockdon, H.F., Doran, K.J., Thompson, D.M., Sopkin, K.L., Plant, N.G., and Sallenger, A.H., 2012, National assessment of hurricane-induced coastal erosion hazards - Gulf of Mexico: U.S. Geological Survey Open-File Report 2012-1084, 51 p., accessed May 15, 2018, at https://pubs.usgs.gov/of/2012/1084/.

Stockdon, H.F., Sallenger, A.H., Jr., List, J.H., and Holman, R.A., 2002, Estimation of shoreline position and change using airborne topographic lidar data: Journal of Coastal Research, v. 18, no. 3, p. 502-513. [Also available at https://www.jstor.org/stable/4299097.]

Vitousek, S.,Barnard, P.L., Limber, P., Erikson, L., and Cole, B., 2017, A model integrating longshore and cross-shore processes for predicting long-term shoreline response to climate change: Journal of Geophysical Research—Earth Surface, v. 122, no. 4, p. 782-806, accessed June 2, 2017, at https://doi.org/10.1002/2016JF004065.

Weber, K.M., List, J.H., and Morgan, K.L.M., 2005, An operational mean high water datum for determination of shoreline position from topographic lidar data: U.S. Geological Survey Open-File Report 2005-1027, accessed May 15, 2018, at http://pubs.usgs.gov/of/2005/1027/.

Yates, M.L., Guza, R.T., and O'Reilly, W.C., 2009, Equilibrium shoreline response-Observations and modeling: Journal of Geophysical Research, v. 114, C9, 16 p., accessed February 2, 2012, at https://doi.org/10.1029/2009JC005359. 
